\title{
PRECARIOUS SETTLEMENTS IN MEXICAN COASTAL CITIES: THE CASE OF CIUDAD DEL CARMEN, CAMPECHE, MEXICO
}

\author{
JOEL F. AUDEFROY ${ }^{1} \&$ EDITH MONTESINOS PEDRO ${ }^{2}$ \\ ${ }^{1}$ Instituto Politécnico Nacional, ESIA (Escuela Superior de Ingenieria y Arquitectura) Tecamachalco, Mexico \\ ${ }^{2}$ Universidad Autónoma del Estado de Morelos, Mexico
}

\begin{abstract}
The purpose of this paper is to present a diagnosis of vulnerability and risk in precarious settlements located in Ciudad del Carmen, Campeche. The methodology used is an analysis of the studied zones, based on physical-environmental determinants of at-risk human settlements. These are: social, economic and physical vulnerability of housing, the various risks and threats they face (such as flooding, sea erosion, hurricanes, pollution), as well as the factors involved in their resilience and adaptation. The diagnostic methodology involved the integration of systemic territorial and social analysis, to illustrate the operating and functional characteristics of the territory's socio-spatial dynamics, in order to explain multivariate phenomena through time and space. This methodological process is applied in an effort to define and question the factors that affect how the system functions, recognizing in all of this the contextual influence of location, city, region and climate. What is interesting about this study is precisely the variability of the humid tropical climate surrounding the irregular, precarious settlements examined in this study.

Keywords: Ciudad del Carmen, disaster mitigation, environmental change, Mexico, settlements, coastal cities, vulnerability, risk, risk study, adaptation, climate variability.
\end{abstract}

\section{INTRODUCTION}

The municipality of Carmen, Campeche has been highly important in the development of the state of Campeche and Mexico overall, due to its geographic position and wealth of natural resources. Initially, there was a boom in the harvesting of palo de tinte [dye wood] and chicle [chewing gum]; then, around the mid 20th century; the fishing, or more specifically shrimping, boom began, setting a new phase in the city's growth and building one of the country's largest fishing fleets. In 1980, Ciudad del Carmen was chosen by the state-owned oil company Petróleos Mexicanos (Pemex) as the site of support and service facilities for offshore oil platforms. Today, the island city of Carmen retains its strategic role in the country's economy, though severely affected by the accelerated growth of such rapidly created poles of development and weather phenomena, such as: hurricanes, flooding, tropical storms and cold fronts. To mitigate the impact of natural phenomena on the island, a risk map was drawn up in 2011, charting its vulnerability to these phenomena. Among other things, the map identified zones that were less or completely unsuitable for housing. To deal with the effects of climate change, the Municipality of Carmen drafted a number of instruments, like the State Emergency Plan for Weather Phenomena, the Municipality of Carmen Atlas of Natural Hazards, and the Urban Master Plan for the Ciudad del Carmen Population Center, Campeche. Nevertheless, Ciudad del Carmen is highly vulnerable to numerous threats, and its capacity for resilience and adaption to those phenomena remains highly questionable.

\section{CONCEPTUAL FRAMEWORK}

There are four key concepts that are useful for understanding the process of disaster mitigation: vulnerability, threat, adaptation and exposure. The articulation of these concepts can be better understood through various examples: 
1. Exposure: this refers to the risk exposure of human settlements and populations that are situated in zones that are generally not suitable for construction, for various reasons (such as soil, flood risk, ravines, unstable slopes...). Exposure, according to Nathan [1], can be divided into two types:

- Physical exposure, which is the presence of settlement, the density of settlement, the habitat, networks, property and services within risk zones, defining the potential damages or losses, both human and non-human; and

- Socio-economic exposure, which is the ecosystemic disturbances that are induced by the presence of man, exacerbated by the natural threat.

2. Vulnerability and threat: These are two in fact inseparable concepts that have been used by various scientific and political communities, with different meanings. The fullest definitions can be found in Hans Günter Brauch [2], in his chapter "Concepts of security threats, challenges, vulnerabilities and risks". Brauch [2] considers vulnerability as both a scientific and a political concept, recognizing the need for more precise definitions, in order to build a stronger consensus on the concepts of vulnerability and threat in particular, for practical action. Nathan [1] distinguishes two major types of approach:

- $\quad$ Single-threat vulnerability models that describe one variable's vulnerability to a given threat as well as models focused on vulnerability to various threats (natural, industrial, etc.). This group includes classic analyses of vulnerability to threats and risk management-focused analyses.

- Analysis focusing on various types of threat, vulnerability to natural threats (earthquakes, hurricanes, torrential rains, etc.) as well as social threats (poverty, marginalization, minorities, disabilities, etc.); at the same time seeking to understand the strategies and aspirations of people in their struggle for a dignified life and a place to live. In this type of analysis, we find literature on livelihoods, households, poverty reduction (in United Nations (UN) reports, in particular), access to assets, human security, popular mitigation, etc.

Nathan [1] points out the real difference between these two approaches, which lies in their relationship to the threat. In fact, they are complementary. We might well begin with the first type of approach: considering the specific vulnerabilities according to the threat, and then placing them in the general context of the actors' social strategies for facing adversity. From a methodological standpoint, this option seems the most appropriate.

3. Adaptation: According to Pelling [3], adaptation is a response (material or institutional) to any aspect of vulnerability. In the field of habitat studies changes can be applied to the design, materials, construction standards or decision-making structures. At the local level, some adaptation processes can be carried out through local governments, through the following actions: regularization of landholding; relocation/rebuilding of at-risk settlements; planning or changes in zoning; updating construction regulations; protecting at-risk infrastructure; improving early alert systems; and supplying alternative infrastructure.

The starting point for a local or federal government that can contribute adaptation mechanisms would be: legislation that recognizes the basic needs and human rights of poor urban populations. Perhaps the most important thing here is the right to housing and to a place to live and work. Guaranteeing the right to land ownership might stimulate local action to invest in neighborhood improvement and in housing and might also help local governments and civil society invest time and money in the social infrastructure to reduce the risk of disaster. 


\section{METHODOLOGY: OPERATING SCHEME AND MAPPING}

As mentioned above, Ciudad del Carmen faces a number of risks: one of the most frequent is flooding. Using as references the Urban Master Plan for the Ciudad del Carmen Population Center [4], as well as the State Emergency Plan for Weather Phenomena [5]; the variables relating to urban sprawl and flood-prone areas were developed, in order to relate them and understand how flood risk developed in that city.

This paper includes a number of maps illustrating the relationships between these variables. The work focused primarily on three variables:

- $\quad$ flood-prone zones;

- $\quad$ population growth, distribution and urbanization; and

- $\quad$ atterns and processes in urban zoning.

\section{CHARACTERIZATION OF RISKS AND THREATS}

\subsection{Hurricanes}

The Municipality of Ciudad del Carmen is threatened by tropical cyclones during the May-November season. These generally originate in the eastern Caribbean and Atlantic Ocean and travel westward toward the Gulf of Mexico, Florida, and the east coast of the US, or dissipate at the cold waters of the north Atlantic. The phenomenon is recurring (Table 1).

Table 1: $\quad$ Recorded hurricanes that affected the state of Campeche, 1988-2012. (Source: Ciudad del Carmen, Atlas of Natural Hazards [6].)

\begin{tabular}{|l|l|l|l|}
\hline Year & Month & Event & Effects \\
\hline 1988 & September & Hurricane Gilberto & $\begin{array}{l}\text { 8 fatalities; 4,000 left homeless; } 10,000 \\
\text { evacuated }\end{array}$ \\
\hline 1993 & June & Tropical storm Arlene & Flooding in various municipalities \\
\hline 1995 & September & Hurricane Opal & 19,000 left homeless \\
\hline 1995 & October & Hurricane Roxanne & 21 deaths; 40,000 left homeless \\
\hline 1998 & September & Hurricane Mich & 13,000 left homeless \\
\hline 2000 & October & Hurricane Keith & 30,000 left homeless \\
\hline 2002 & September & Hurricane Isidore & Heavy damage and 500,000 affected \\
\hline 2003 & October & Hurricane Larry & Winds of $95 \mathrm{~km} / \mathrm{h}$ \\
\hline 2005 & October & Hurricane Stan & Winds of $75 \mathrm{~km} / \mathrm{h}$ (up to $130 \mathrm{~km} / \mathrm{h}$ in gusts) \\
\hline 2007 & August & Hurricane Dean & $\begin{array}{l}\text { Winds of } 155 \mathrm{~km} / \mathrm{h}(\text { up to } 260 \mathrm{~km} / \mathrm{h} \text { in } \\
\text { gusts })\end{array}$ \\
\hline 2008 & May-June & Hurricane Arthur & Winds of $75 \mathrm{~km} / \mathrm{h}$ \\
\hline 2012 & August & Hurricane Ernesto & Wind and rain \\
\hline
\end{tabular}

In 1988, Hurricane Gilbert struck Yucatán and Campeche, causing eight deaths and leaving 40,000 and 30,000 residents homeless, respectively. In Ciudad del Carmen, Campeche, hurricanes Roxanne and Opal destroyed the shrimp loading piers for two freezing plants, and all of the stands in the popular fish and seafood market. During the night of 
November 3, hurricane Mitch made landfall in the state of Campeche approximately $70 \mathrm{~km}$ northeast of the capital city, leaving 13,000 homeless in its wake.

In 2002, hurricane Isidore wreaked heavy damage on livestock herds and farmland, downed electrical and telephone lines and damaged or destroyed thousands of homes.

\subsection{Flooding}

Flooding is one of the most high-impact risks in this municipality, and the area from the Atasta peninsula to Nuevo Campechito are the zones that are at the greatest risk of flooding, as well as the zones close to the lagoon. Flooding occurs when the sea rises well above its normal levels, due to storms, and because of the abundant rainfall originating throughout the watershed basin to which the region belongs. For example, the municipality has seven high-precipitation zones, which range from $1300 \mathrm{~mm}$ to $1900 \mathrm{~mm}$. In most of the territory, the land is flat, with elevations of no more than $2.5 \mathrm{~mm}$. This increases the risk of flooding.

In 2011, in response to a state of emergency caused by the overflow of the Palizada river, the government authorized funding totaling Ps. 478,299,381 to mitigate the flood damage, which went to repair state and federal infrastructure to do with the water supply, sports facilities, highways, healthcare and solid waste management systems. The following is a list of the districts (colonias), streets, and geographic points in the central and western zone of the city that are vulnerable to flooding, which results from heavy rain, and which may have been caused by weather phenomena like cyclones, tropical floods and hurricanes (Table 2).

Table 2: $\quad$ Flood-prone districts in the urban zone of Ciudad del Carmen. (Source: prepared by EMP based on: Ciudad del Carmen, Atlas of Natural Hazards [6].)

\begin{tabular}{|l|l|}
\hline District & Number of homes at risk \\
\hline Colonia Manigua & 1,399 inhabited private homes \\
\hline Colonia Caracol & 468 inhabited private homes \\
\hline Colonia Miguel de la Madrid & 810 inhabited private homes \\
\hline Colonia Estrella & 375 inhabited private homes \\
\hline Colonia Centro & 1,540 inhabited private homes \\
\hline Colonia Tecolutla & 1,348 inhabited private homes \\
\hline Colonia Revolución & 309 inhabited private homes \\
\hline Colonia Justo Sierra & 1,078 inhabited private homes \\
\hline Colonia 23 de Julio & 897 inhabited private homes \\
\hline Colonia Arcila & 467 inhabited private homes \\
\hline Santa Isabel & 939 inhabited private homes \\
\hline Fracc. Santa Rita & 623 inhabited private homes \\
\hline Tierra y Libertad & 348 inhabited private homes \\
\hline Bivalvo II & $\begin{array}{l}382 \text { homes made of wood, zinc laminate and } \\
\text { cardboard }\end{array}$ \\
\hline José Ortiz Ávila & 573 precarious homes \\
\hline El Potrero & 5 precarious homes \\
\hline Total & 11,179 homes \\
\hline
\end{tabular}


According to Table 2, more than 11,000 homes are at risk of flooding, and some of them are precariously built. Whether or not these human settlements were planned, it is clear that may streets have a tendency to flood and accumulate standing water for various reasons, which makes the local inhabitants be prone to certain types of illnesses borne by mosquitoes coming from standing water larvae, and also property damage.

\subsection{Precipitation/high tides}

Hurricanes are most damaging when two phenomena combine: first, extraordinary rainfall in the southeast of the country, which brings more water into the seven river branches that reach the lagoon; and second, high tides. The result of these two phenomena is that the "outlets" formed between the island and the continent are obstructed by the tide and the water coming in from the rivers is turned back, resulting in a rise in sea level that floods the coast and enters dry land, damaging urban facilities and in particular, precarious neighborhoods.

\subsection{Sea erosion}

There is photographic evidence of erosion happening on the coastal edges of the municipality of Carmen, which grows worse during hurricane and storm season. This erosion is evident along the coastline between Isla Aguada and Ciudad del Carmen, in a zone very close to the Mexican federal highway 180, in the Municipality of Carmen, close to the community of Isla Aguada, along the Ciudad del Carmen-Champotón segment and the part of the road between $161 \mathrm{~km}$ and $163 \mathrm{~km}$ of the same highway [6].

\subsection{Pollution}

There are four sources of environmental pollution in Ciudad del Carmen:

1. Disruption of natural drains. The phenomenon of urban sprawl has interrupted the natural flow of rainwater toward water bodies or the sea, because of barriers that are formed by streets, irregular settlements, accumulation of sediment, and more.

2. Pollution leached from trash dumps and cemeteries. Although the company that holds the municipal waste management concession has improved the dump greatly, this has not reached the level of being a sanitary landfill, which means what leaches can reach the water table.

3. Water table contamination. Only $3 \%$ of homes on the island have sanitary drainage. The rest use septic tanks, and most of them are not built appropriately, which means there is more sewage filtering into the water table and contaminating it.

4. The invasion of mangroves, because of growing informal urbanization.

\subsection{Invasion of seawater and the rise in sea level}

Ciudad del Carmen is at a clear disadvantage when sea levels rise, because the maximum elevation in the city is only around two meters. If the sea level rises by a meter and a half, almost $80 \%$ of the city would be under water. Ciudad del Carmen has already seen flooding of more than a meter, but in those cases the waters eventually receded to the ocean.

Between 1956 and 1991, the sea level rose $3.4 \mathrm{~mm} /$ year, meaning there has already been a rise of almost $12 \mathrm{~cm}$ total, according to reports cited in work by Pedrozo Acuña [7]. A rise in sea level means permanent flooding: a $50-\mathrm{cm}$ rise in sea level, which in a worst-case 
scenario could happen in a matter of decades, would wipe out close to 2,300 homes and flood $22 \%$ of the city's current area [8].

\section{DIAGNOSIS OF FLOOD VULNERABILITY}

In Fig. 1, we can see that since 1929, when urban sprawl was confined to the northeast of the city, despite being far from the mangroves, the city was already located from the start in a flood-prone area. This first area of urban sprawl has always served as a zone for retail provisioning, and for serving marine trade routes.

Between 1950 and 1986 (Fig. 2), the city's footprint more than tripled over its original 1929 shape, for two main reasons: first, the construction of an airport in the 1950s, which almost doubled the size of the city in the ensuing 20 years; and second, oil infrastructure that arrived in 1980, with offshore platforms that swelled the size of both the city and its population along with the creation of new jobs. Responding to this increase in the population and haphazard growth forming urban sprawl during that period, the First Urban Program was drawn up in 1986, in an effort to organize the city and control the destruction of the mangroves, because this was also the first time this natural habitat began to be destroyed by urbanization.

Fig. 3 shows the city growing in an uncontrolled manner toward the mangroves and the low-lying flood plains, which means the First Urban Program of 1986 was unsuccessful in controlling the city's growth. Between 1956 and 1991, the sea level rose $3.4 \mathrm{~mm}$ per year, almost $12 \mathrm{~cm}$ in all, according to reports cited in the work by Pedrozo Acuña [7]. Rising sea levels means more accumulated standing water and flooding: these have become more frequent with climate change. With the arrival of the airport and the oil industry, Ciudad del Carmen grew by more than twice as much as it had in 1928-1998, in just 10 years.

In response to the city's growth, as in the period from 1990 to 2000, along with rising sea levels and recurrent flooding and natural disasters, the first Risk Map was created in 2011; since (as Fig. 4 shows) by this time practically $90 \%$ of the city was located in flood-prone areas. Although the land there is not apt for housing, the city's outlines can be seen growing toward the northeast of the city in 2018: most of this growth being irregular housing.

By 2018, practically all of the city was vulnerable to flooding (Fig. 5), but with reference to Table 1, the districts with precarious housing (marked in red) are: Bivalvo II with 383 homes, José Ortiz Ávila with 573 homes and El Potrero with 5 homes. This makes these three districts the most vulnerable to flooding during the rainy season; plus also because of the socio-economic status of the inhabitants, who are forced to build cheaper and flimsier homes out of wood, cardboard, zinc laminate, and more; which are not very resilient home-building materials in the context of this risk.

\section{CONCLUSIONS}

The increase in risks and disasters caused by climate variability in the urban areas of Ciudad del Carmen, Mexico, has a double anthropic dimension: It is linked to the anthropization of hazards (for example, floods due to urban runoff) and to the increase in the vulnerability of local societies. Disasters are also linked to a complex chain of interactions between urbanization and meteorological phenomena, as cities undergo a profound transformation under the influence of climatic, demographic and environmental changes, and particularly for the coastal cities that are most exposed to threats.

In the case of Ciudad del Carmen, where the housing is particularly vulnerable, $34.74 \%$ of the urban area is assigned to housing, prevailing in it: the one and two-level single-family housing, with a predominance in the western sector of low density to average density (from 


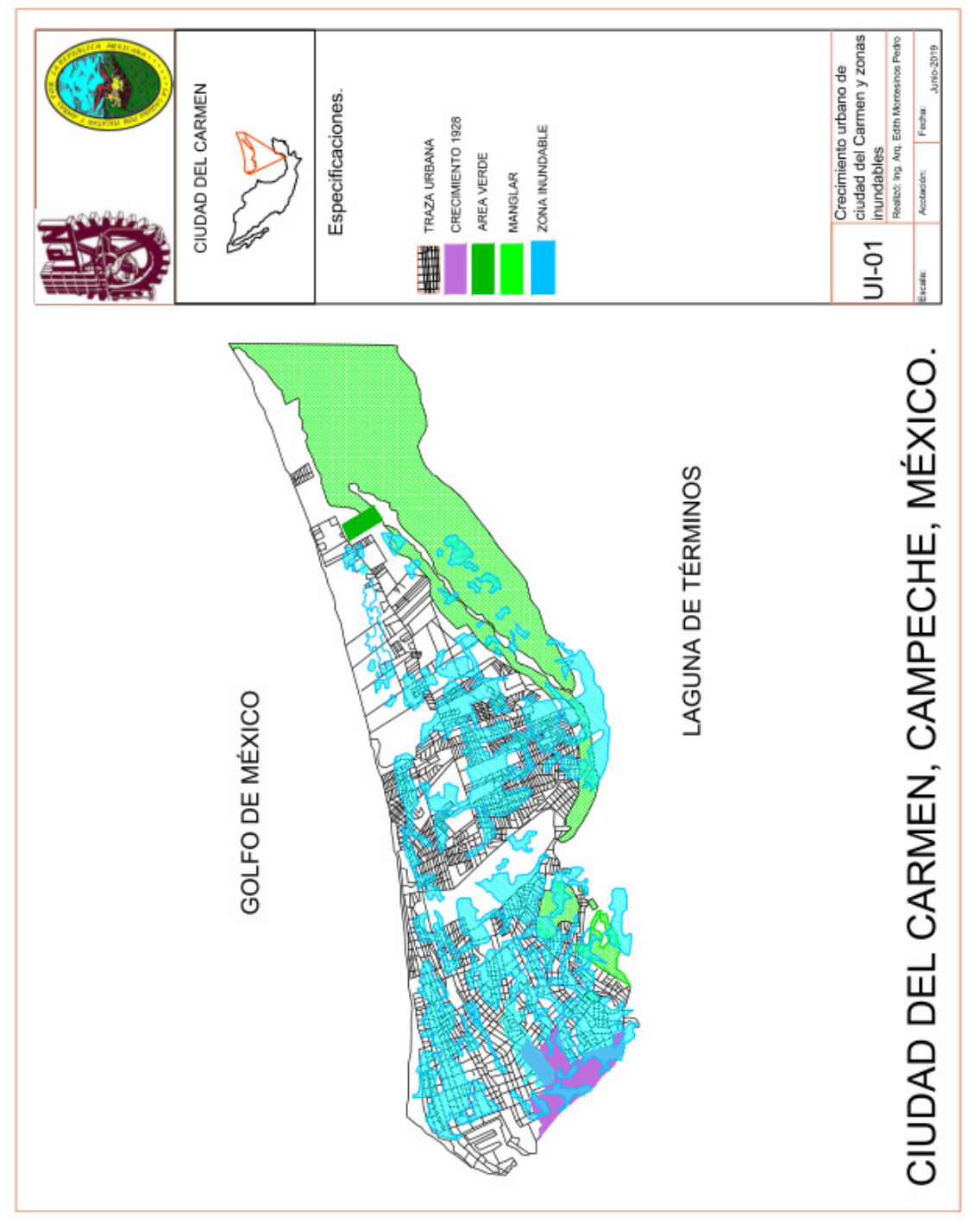

ฮิ

ธิ

ปี่

ร

ช

है के

₹

되

วิ

ช

ㅇำ

है ई

نे

ป

ง $\frac{1}{1}$

ลิ จำ

ลิ :

ฮิ

อิำ

记

㱐

बे

言

$\tilde{U}$

호

홍 : ฐ

$4 \hat{0}$ है

ช ะ

ప ธ

茫

ส

రิ

पे दे

히

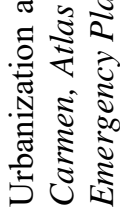

$\underset{\ddot{0}}{\ddot{0}}$ 


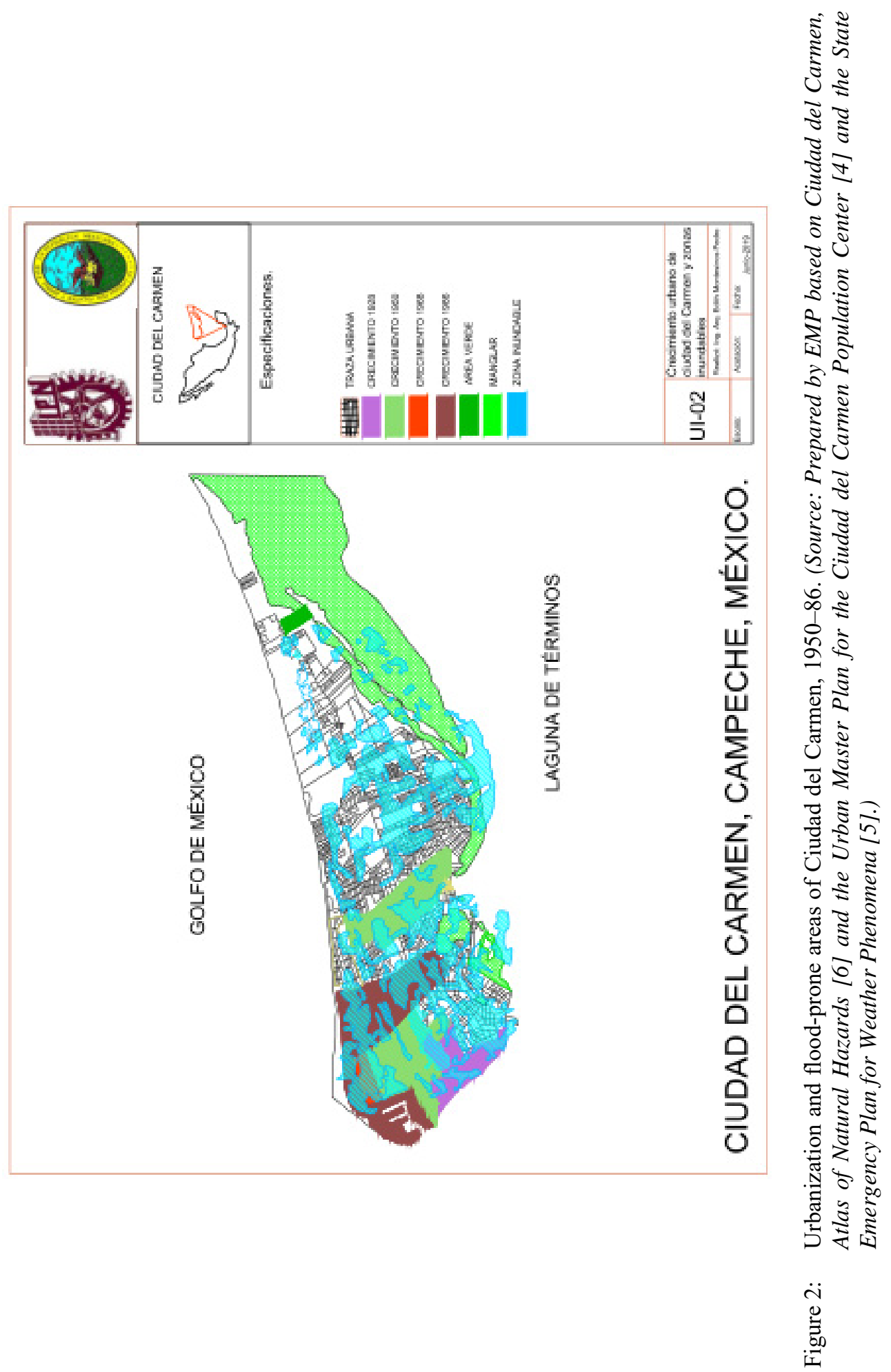




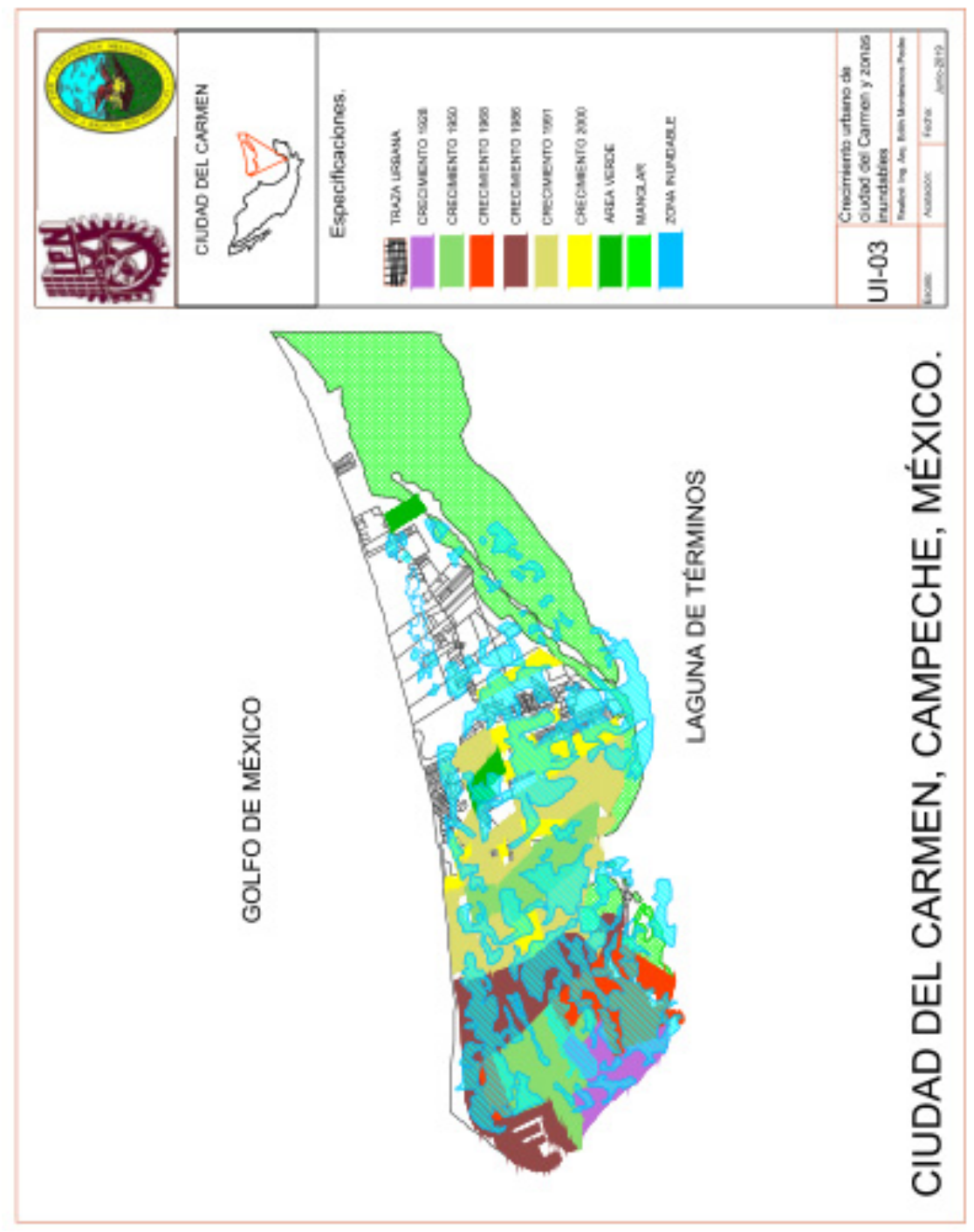

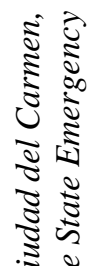

ษ

ธิ ธิธ

ปั

के

$\sum_{i=1}^{0} \frac{0}{2}$

고

ปู

ธิ ฐ

5

iे ई

ริ

胥

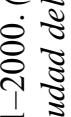

ลे

2

อี อิ

氜

व

구

을

บ

눙

ฮै

ช

药

눈

:

cis

उ ฮ

.ี ธิ ธิ

氙艾这

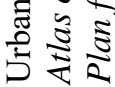

$\ddot{\sim}$ 


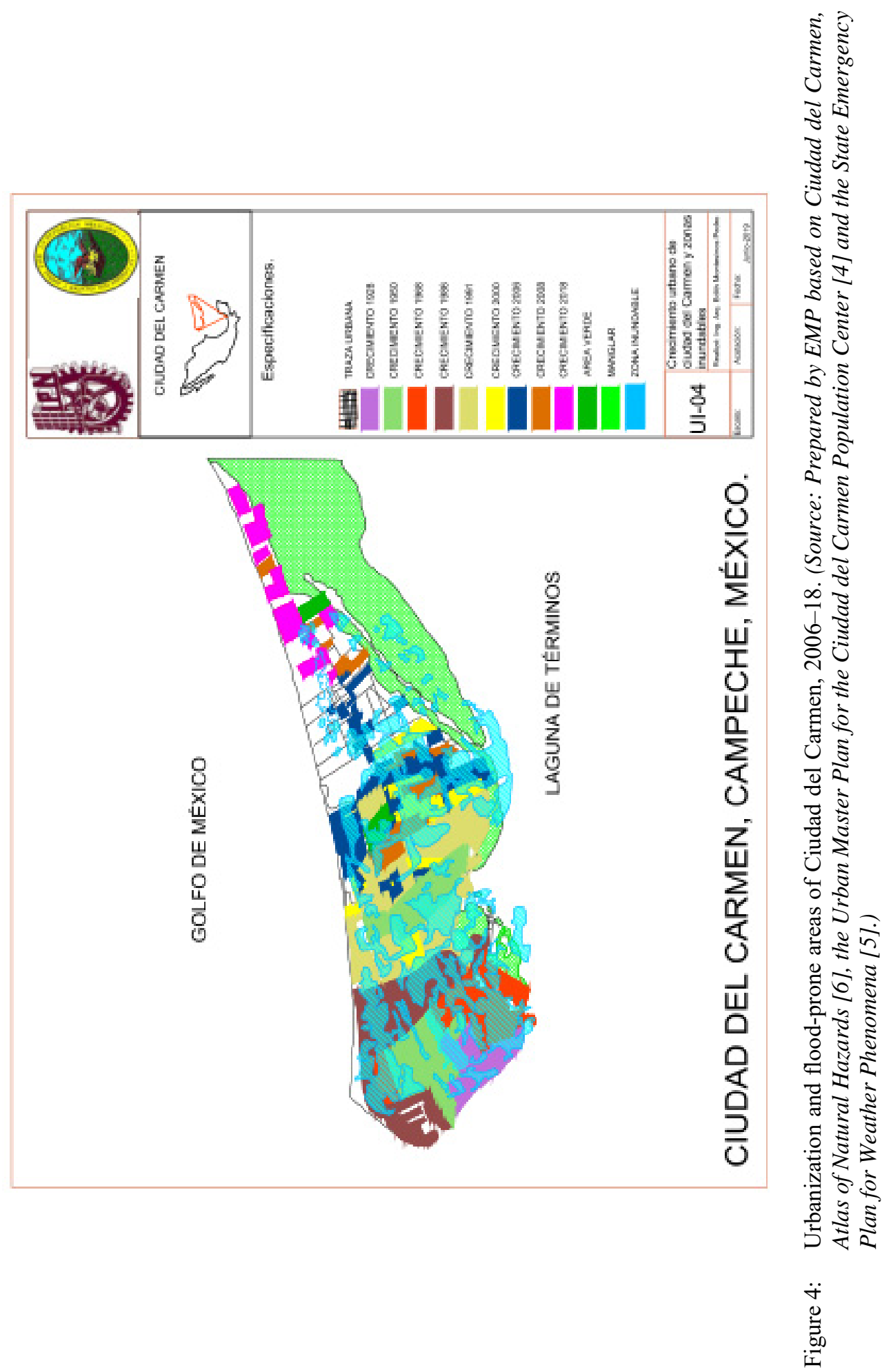




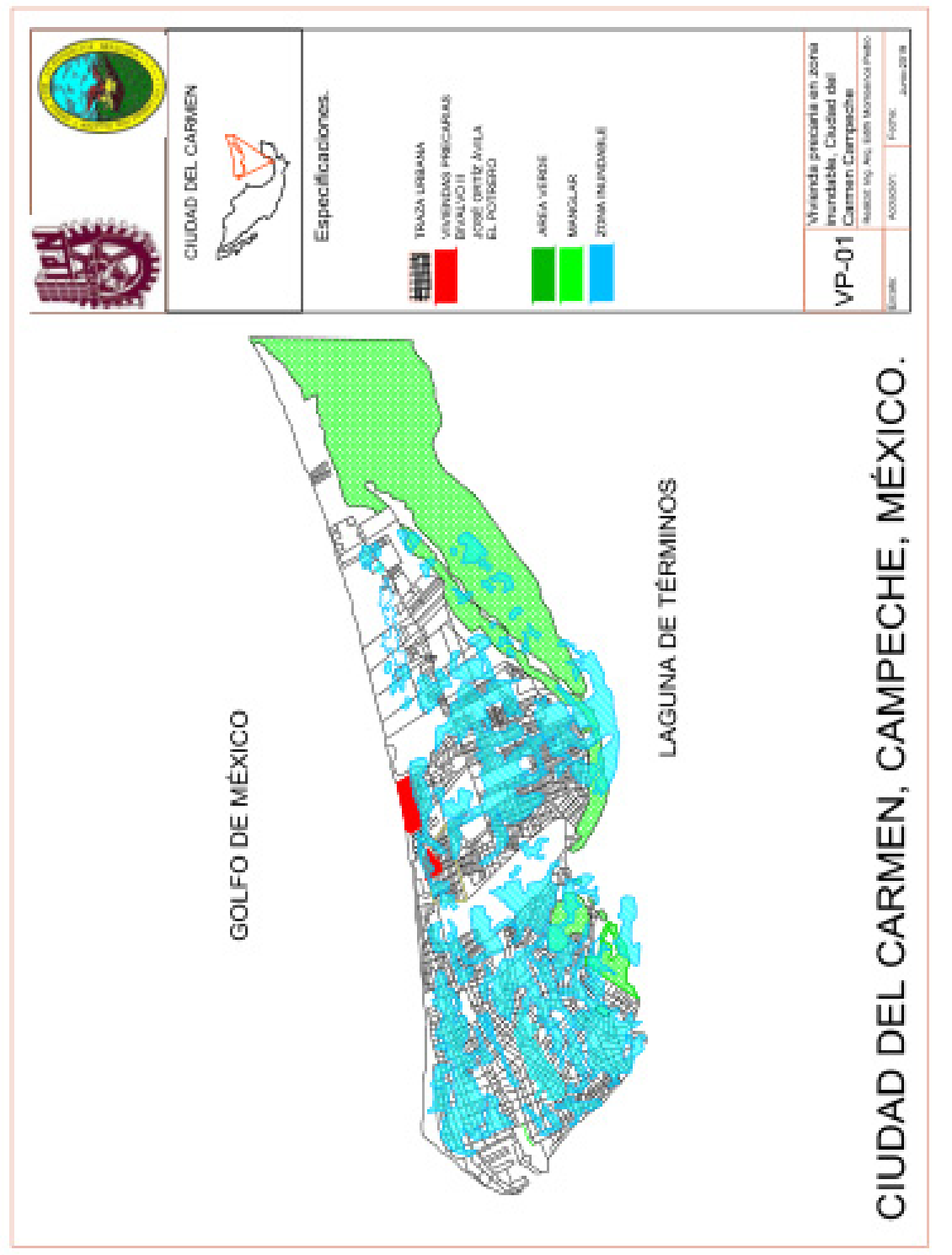

¿े

$\frac{\tilde{z}}{\frac{\pi}{2}} \frac{\delta}{2}$

छे टे

हิ ธิ

ن छे

莽

$\frac{0}{0}$

ปี

ธิ

ป

$8 \div$

₹

ते

ป ำ

ปิ

के ००

$2 \frac{1}{2}$

نे ई

ธิ

S $\frac{0}{0}$

อี

తే

$\overline{8} \frac{1}{2}$

चี

递

政

है छे

ส

\&

을 ई

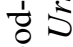

은

$\because \ddot{\sigma} \because$

0,0

की

ธิ ธิ

a $\frac{1}{2}$

응

氖

2 $z 3$

$\underset{\sim}{\ddot{0}}$ 
26 to 60 houses/ha) and in the eastern sector, dominated by high density (more than 61 houses/ha). The urban and conurbated area of the city covers about $25 \%$ of the island; there is only $15 \%$ more living space, since the remaining $60 \%$ corresponds to mangrove swamps that are not suitable for urban development [10].

Climate change will increase coastal flooding and erosion in the future. In addition, a greater number and intensity of tropical storms and hurricanes are also expected, so there will be an increase in the probability of the incidence of extreme storm surges on the coasts $(\sim 4$ to $6 \mathrm{~m})$. The tides can cause the affected areas to extend between 11 and $16 \mathrm{~km}$ inland, into low areas that are only $1-2 \mathrm{~m}$ above sea level [7].

The key question is, "How can coastal zones be transformed into systems that are more resilient and adaptive to a rising incidence of large disturbances?" (Adger [9]). It would seem that, in some regions of the country, adaptations have included changes in the rules and comprehensive management of the hurricane and flood risks, changes in organizations, creation of early alert systems, and self-mobilizing social movements and actions undertaken by private enterprise. Social learning, the diversity of adaptations, and the promotion of stronger local cohesion and collective action mechanisms have all improved resilience, and they continue to guide planning for future climate change.

\section{ACKNOWLEDGEMENTS}

This work was produced within SIP research project No. 20195369, financed by the graduate program via the Secretaria de Posgrado e Investigación of the Instituto Politecnico Nacional in 2019, with funding from the Mexican federal government.

\section{REFERENCES}

[1] Nathan, F., Comprendre le risque et la vulnérabilité: une perspective de sciences sociales á propos des risques de glissement de terrain à La Paz, Bolivia. Risques et environnement: recherches interdisciplinaires sur la vulnérabilité des sociétés (Risks and the environment: Interdisciplinary research on societal vulnerabilities), eds S. Becerra \& A. Peltier, L'Harmattan: Paris, pp. 117-128, 2009.

[2] Günter Brauch, H., Concepts of security threats, challenges, vulnerabilities and risks. Coping with Global Environmental Change, Disasters and Security, eds H. Günter Brauch et al., Springer: Heidelberg, pp. 61-106, 2011.

[3] Pelling, M., The vulnerability of cities to disasters and climate change: A conceptual framework. Coping with Global Environmental Change, Disasters and Security, eds H. Hans Günter Brauch et al., Springer: Heidelberg, pp. 549-558, 2001.

[4] IMPLAN, Programa director urbano del centro de población de Ciudad del Carmen Campeche (Program directing urban planning of the center of the population of the City of Campeche), p. 158, 2009. www.implancarmen.org/pdf/pdu/Tomo_I.pdf.

[5] CENECAM, Plan Estatal de contingencias para fenómenos hidrometeorológicos (State plan for contingencies for hydrometereological phenomena), p. 139, 2013. www.proteccioncivil.gob.mx/work/models/ProteccionCivil/swbcalendario_Elemento Seccion/655/PLAN_ESTATAL_CONTINGENCIAS_PARA_FENONEMOS_HIDR OMETEOROLOGICOS_2014.PDF.

[6] CGASI (Consultoría, Gestoría Ambiental y Seguridad Industrial), Atlas de peligros naturales, Ciudad del Carmen (Atlas of natural disasters for Ciudad del Carmen), 2011. www.carmen.gob.mx/transparencia/web/Ayuntamiento/2014/OB23/ATLAS_DE_PE LIGROS_CARMEN_2011.pdf. 
[7] Pedrozo Acuña, A., Impactos del Incremento en el Nivel Medio del Mar en la Zona Costera del Estado de Campeche, México (Impact of increasing sea levels on coastal zones of the state of Campeche, Mexico), World Bank: Washington, p. 92, 2012.

[8] Perez de Francisco, R., Sea Level Rise Sustainable Coping Options for Ciudad del Carmen, Mexico, Thesis for MSc in Environmental Management, Christian-AlbrechtsUniversität zu Kiel, p. 63, 2010.

[9] Adger, N.W., Social-ecological resilience to coastal disasters. Science, 309, pp. 10361039, 2005.

[10] Gobierno Municipal del Carmen, Plan municipal de desarrollo 2012-2015 (Municipal plan for development 2012-2015), p. 152, 2013. 